\title{
CARM1 Modulators Affect Epigenome of Stem Cells and Change Morphology of Nucleoli
}

\author{
M. FRANEK ${ }^{1}$, S. LEGARTOVÁ ${ }^{1}$, J. SUCHÁNKOVÁ ${ }^{1}$, C. MILITE ${ }^{2}$, S. CASTELLANO ${ }^{2}$, \\ G. SBARDELLA ${ }^{2}$, S. KOZUBEK ${ }^{1}$, E. BÁRTOVÁ ${ }^{1}$ \\ ${ }^{1}$ Institute of Biophysics, Czech Academy of Sciences, Brno, Czech Republic, ${ }^{2}$ Epigenetic \\ MedChem Lab, Università di Salerno Dipartimento di Farmacia, Salerno, Italy
}

Received November 5, 2014

Accepted February 17, 2015

On-line June 5, 2015

\begin{abstract}
Summary
CARM1 interacts with numerous transcription factors to mediate cellular processes, especially gene expression. This is important for the maintenance of ESC pluripotency or intervention to tumorigenesis. Here, we studied epigenomic effects of two potential CARM1 modulators: an activator (EML159) and an inhibitor (ellagic acid dihydrate, EA). We examined nuclear morphology in human and mouse embryonic stem cells (hESCS, mESCs), as well as in iPS cells. The CARM1 modulators did not function similarly in all cell types. EA decreased the levels of the pluripotency markers, OCT4 and NANOG, particularly in iPSCS, whereas the levels of these proteins increased after EML159 treatment. EML159 treatment of mouse ESCs led to decreased levels of OCT4 and NANOG, which was accompanied by an increased level of Endo-A. The same trend was observed for NANOG and Endo-A in hESCs affected by EML159. Interestingly, EA mainly changed epigenetic features of nucleoli because a high level of arginine asymmetric di-methylation in the nucleoli of hESCs was reduced after EA treatment. ChIP-PCR of ribosomal genes confirmed significantly reduced levels of H3R17me2a, in both the promoter region of ribosomal genes and rDNA encoding $28 \mathrm{~S}$ rRNA, after EA addition. Moreover, EA treatment changed the nuclear pattern of AgNORs (silver-stained nucleolus organizer regions) in all cell types studied. In EA-treated ESCs, AgNOR pattern was similar to the pattern of AgNORs after inhibition of RNA pol I by actinomycin D. Together, inhibitory effect of EA on arginine methylation and effect on related morphological parameters was especially observed in compartment of nucleoli.
\end{abstract}

\section{Key words}

Epi-drugs • Histones • Epigenetics $\bullet$ ES cells $\bullet$ iPS cells $\bullet$ Nucleoli

\section{Corresponding author}

E. Bártová, Institute of Biophysics, Czech Academy of Sciences, v.v.i., Královopolská 135, 61265 Brno, Czech Republic. Fax: +420-541240498. E-mail: bartova@ibp.cz

\section{Introduction}

Coactivator-associated-protein-arginine-methyltransferase 1 (CARM1) is an arginine methyltransferase that is responsible for asymmetric di-methylation of histone $\mathrm{H} 3$ at the arginine 17 or 26 positions (H3R17 or H3R26). It also methylates nonhistone substrates, including PABP1 and p300 proteins. The activity of this enzyme was first described in relation to a well-known family of p160 coactivators (Chen et al. 1999). Various levels of CARM1 protein have been identified in different tissues, and it has been reported that CARM1 activity is required for the proper maintenance of physiological processes such as endochondral ossification and chondrocyte proliferation (Ito et al. 2009), myogenesis (Batut et al. 2011), glycogen metabolism (Wang et al. 2012), and control of proliferation and differentiation of pulmonary epithelial cells (O'Brien et al. 2010). Indeed, mice lacking functional CARM1 gene are non-viable and die perinatally (Yadav et al. 2003). Moreover, TorresPadilla et al. (2007) showed that CARM1 protein, which is asymmetrically distributed in four-cell embryos, contributes significantly to cell fate decision. High levels of CARM1, as well as H3R2 or H3R17 dimethylation (H3R2me2 or H3R17me2), contribute to

PHYSIOLOGICAL RESEARCH • ISSN 0862-8408 (print) • ISSN 1802-9973 (online)

(c) 2015 Institute of Physiology v.v.i., Academy of Sciences of the Czech Republic, Prague, Czech Republic

Fax +420 241062 164, e-mail: physres@biomed.cas.cz, www.biomed.cas.cz/physiolres 
a pluripotent state of cells of the inner cell mass (ICM) of blastocyst, whereas cells with lower CARM1 levels are predestined to become part of the differentiation phenotype of the mural trophoectoderm. Interestingly, high levels of embryonic histone H3 methylation and CARM1 expression are responsible for pluripotency gene up-regulation. This guarantees optimal conditions for pluripotent cells in the ICM (Wu et al. 2009). Therefore, it is evident that CARM1 is required for the self-renewal and pluripotency of embryonic stem cells (ESCs). In these cells, CARM1 depletion downregulates pluripotency genes, which initiate differentiation processes (Wu et al. 2009).

It is generally accepted that the expression of the majority of genes is guaranteed by their interaction with specific transcription regulator complexes and chromatin modifying enzymes. CARM1 interacts with numerous transcription factors to mediate cellular processes, often in conjunction with chromatin modifiers such as p300. For example, Covic et al. (2005) reported that NF- $\kappa B$ utilizes both CARM1 and p300 to stimulate the transcription of genes involved in inflammatory processes and apoptosis. However, all NF- $\kappa \mathrm{B}-$ regulated genes are not dependent on CARM1 function. It is evident that CARM1 is involved in many cellular events that are related to stem cell pluripotency as well as cell differentiation. This enzyme has been shown to regulate chondrogenesis by modulating Sox9 function, a transcription factor essential for proper differentiation of mesenchymal cells into chondroblasts. Together, CARM1 and Sox9 regulate cyclin D1 expression in chondrocytes. These data explain why skeletal abnormalities are observed in CARM1-deficient embryos (Ito et al. 2009). Interestingly, CARM1mediated post-translational modifications of proteins impact the differentiation pathways into skeletal muscles. For example, $\operatorname{Pax} 7$ is a transcription factor that is methylated by CARM1, which in turn regulates expression of an additional myogenic transcription factor, Myf5. This cellular event leads to the production of myogenic progenitors (Kawabe et al. 2012). Moreover, CARM1 activity is crucial for tumor progression. For example, Ou et al. (2011) reported that CARM1 is overexpressed in colon cancer cells, where it interacts with $\beta$-catenin and activates transcription of genes that are regulated by the $\mathrm{Wnt} / \beta$-catenin signaling pathway. CARM1 depletion in the human colorectal carcinoma cell line HT29 represses anchorage independent growth, a typical mark of transformed cells. It is also well established that CARM1 is an estrogen receptor-mediated transcriptional co-activator. Thus, it is reasonable hypothesize that nonphysiological CARM1 expression might play a role in breast cancer progression. A preclinical study has demonstrated that there is a positive correlation between CARM1 expression and aggressive tumor behavior (Cheng et al. 2013). At the molecular level, CARM1 expression correlates with the expression of markers such as HER2, pKi-67, EGFR, or cyclin E, which represent key players that regulate the high proliferation rate of breast cancer cells (Habashy et al. 2013).

Based on these data, there is convincing evidence that CARM1 represents a very important and ubiquitous regulatory factor involved in the regulation of many cellular processes, including the maintenance of ESC pluripotency and tumorigenesis (Habashy et al. 2013, Wu et al. 2009). Many studies have aimed to understand CARM1 role in physiological and pathological processes. These studies gain insight into its catalytic mechanism, as well as lead to development of small-molecule modulators of CARM1 activity. Among the compounds described thus far, ellagic acid (EA) represents a site-specific inhibitor of CARM1 (Allan et al. 2009, Bonham et al. 2010, Castellano et al. 2010, Dowden et al. 2011, Habashy et al. 2013, Huynh et al. 2009, Cheng and Bedford 2011, Cheng et al. 2011, Purandare et al. 2008, Sack et al. 2011, Therrien et al. 2009, Wan et al. 2009, Selvi et al. 2010). EA was identified in pomegranate and other fruit extracts. Interestingly, it binds to the XXPRX/XXRPX motif on histone $\mathrm{H} 3$, but does not directly bind to the catalytic domain of CARM1 (Kim et al. 2004). However, H3R26 methylation, which is also mediated by CARM1, is not inhibited by EA because it does not contain the prolinearginine motif (Selvi et al. 2010). In contrast, a series of compounds (aryl ureido acetamido indole carboxylates, termed "uracandolates"), acting as CARM1 activators, have recently been reported. These compounds increase the CARM1-mediated methylation of histone $\mathrm{H} 3$ or nonhistone proteins (polyadenylate-binding protein 1, PABP1). This which was confirmed in protein substrates and also on cellular level (Castellano et al. 2012, Zeng et al. 2013). Therefore, in this study, we examined the effects of EA and EML159 (an uracandolate compound) in mouse or human ESCs, as well as in mouse iPSCs. We analyzed the effect of these two epi-drugs on pluripotency markers, the histone signature, and morphology of the nucleoli. 


\section{Materials and Methods}

\section{Cell culture}

We cultivated mouse ESCs, lines D3 (ATTC $^{\circledR}$ CRL-1934 ${ }^{\mathrm{TM}}$ ) and primary induced mouse pluripotent stem cells, line WP5 (Stemgent ${ }^{\mathrm{TM}}$, USA, cat. no.: \#080007). Studies were also performed using human embryonic stem cells (line CCTL-017, a derivative cell line of CCTL-12, a gift from the Department of Biology, Faculty of Medicine, Masaryk University, Brno, Czech Republic). Mouse embryonic stem cells (mESCs) and iPSCs were cultivated in Dulbecco's Modified Eagle Medium (DMEM), supplemented with penicillin and streptomycin, non-essential amino acids, mouse leukemia inhibitory factor, monothioglycerol, and $15 \%$ fetal bovine serum (Šustáčková et al. 2012). Human embryonic stem cells were cultured in the defined, commercially available medium, mTESR1 (Stemcell technologies, \#05870). Mouse ESCs were cultured on $0.1 \%$ gelatin coated plastic dishes ( $\mathrm{Nunc}^{\mathrm{TM}}$, Germany). Human ESCs were cultured on Matrigel-coated plates (Corning ${ }^{\circledR}$ Matrigel $^{\circledR}$ hESC-Qualified matrix, \#354277, Corning). Media were changed daily, and cells were dissociated using trypsin. To ensure minimal levels of spontaneous differentiation, human ESCs were passaged every 5-6 days, whereas murine stem cells were passaged every 2-3 days. For experiments, cells were harvested at approximately $80 \%$ confluence.

Human embryonic stem cells (CCTL-017) were maintained according to Czech national law 227/2006 and Ethics Committee agreement No.616/2012/31.

\section{Treatment of cells with small molecular compounds}

Cell lines were treated for $24 \mathrm{~h}$ with the CARM1 activator (EML159, Fig. 1Aa) (Castellano et al. 2012) or the CARM1 inhibitor (ellagic acid, EA, Fig. 1Ab) (Selvi et al. 2010). The concentrations used to treat different cell lines were established empirically according to the cell growth (Fig. 1Ba-c). EML159 was used at $150 \mu \mathrm{M}$, whereas EA was used at $150 \mu \mathrm{M}$ for mESCs and $110 \mu \mathrm{M}$ for hESCs. Differences in EA concentrations are due to the different sensitivities of mESCs and hESCs to this compound. We tried to find concentrations that affect asymmetric H3R17me2 (Fig. 1Ca-c), but did not change the morphology of F-actin filaments, a main compounds of the cytoskeleton (Albert et al. 2002; Fig. 2A-C). In hESCs, EA decreased the entire level of H3R17me2 when normalized to total histone H3 (Fig. 1Cc, quantification in panel 1Dc).
Immunofluorescence analyses and cell visualization by confocal microscopy

For immunofluorescence analyses, cells were washed in phosphate-buffered saline (PBS) and fixed for 15 to $20 \mathrm{~min}$ in $4 \%$ formaldehyde. Cells were permeabilized by subsequent treatment with $0.1 \%$ Triton-X (8 min) and $0.1 \%$ saponin (12 min) solutions. Cells were washed in PBS and blocked for $1 \mathrm{~h}$ using $1 \%$ BSA in PBS. After blocking, cells on microscope slides were incubated overnight with the primary antibody diluted $1: 100-1: 200$ in $1 \%$ BSA solution. Cells were washed in PBS and incubated with secondary antibodies conjugated to either Alexa 488 or Alexa 594. Finally, DNA was stained using 4',6diamidino-2-phenylindole (DAPI). The primary antibodies were as follows: anti-OCT4 (\#sc5279, Santa Cruz Biotechnology), anti-ASYM24 (\#07-414, UpstateMillipore), anti-fibrillarin (\#ab5821, Abcam), and antiH3K9me3 (\#07-442, Upstate-Millipore). The secondary antibodies were anti-mouse or anti-rabbit antibodies conjugated to either Alexa-488 or Alexa-594 (\#A21206, \#A21202, \#A21203, \#A21207, Invitrogen, Molecular Probes).

Specimens were examined using confocal microscopy (Leica SP5 X, Leica Microsystems, Mannheim, Germany) with the following settings: $1024 \times$ 1024 pixels, $400 \mathrm{~Hz}$, bidirectional mode, zoom 8-12. Leica software (LEICA LAS AF, version 2.1.2) was used for image acquisition as previously described (Stixová et al. 2012).

\section{Western blot analyses}

Western blot analyses were performed according to Stixová et al. (2012). For analyses, we used the following primary antibodies: anti-OCT4 (\#sc5279, Santa Cruz Biotechnology); anti-NANOG (mouse specific \#ab80892, Abcam); anti-NANOG (human specific \#sc293121, Santa Cruz Biotechnology); anti-Endo-A (kindly provided by Dr. Jiří Pacherník, Masaryk University, Brno, Czech Republic); anti-fibrillarin (\#ab5821, Abcam); anti-UBF1/2 (\#ab75781, Abcam); anti- $\alpha$-tubulin (\#LF-PA0146, Fisher-Scientific); antihistone H3 asymmetric R17 dimethylation (me2) (\#ab8284, Abcam). Total protein levels were measured by $\mu$ Quant spectrophotometer (BioTek).

Chromatin immunoprecipitation assays and polymerase chain reaction (ChIP-PCR)

Chromatin immunoprecipitation was performed 
according to the manufacturer's protocol (ChIP Assay Kit, Millipore; \#17-295). Briefly, we used equal numbers of cells $\left(1 \times 10^{6}\right)$ and added formaldehyde (final concentration of $1 \%$ for $10 \mathrm{~min}$ ) directly to the culture media. Cells were washed with PBS containing a protease inhibitor cocktail [1 $\mathrm{mM}$ phenylmethylsulfonyl fluoride (PMSF), $1 \mu \mathrm{g} / \mathrm{ml}$ aprotinin, and $1 \mu \mathrm{g} / \mathrm{ml}$ pepstatin A]. Cells were treated in lysis buffer containing sodium dodecyl sulfate (SDS), lysed for $10 \mathrm{~min}$ on ice, followed by sonication. Histone-DNA complexes were incubated with $5 \mu$ l of the appropriate antibody (anti-histone H3 asymmetric R17me2, ChIP grade; \#ab8284, Abcam). As negative controls, we used samples precipitated without antibody and samples immunoprecipitated with antirabbit IgG (IgG whole molecule, Sigma-Aldrich, Czech Republic, \#A-4914). Immunoprecipitation reactions were performed overnight at $4{ }^{\circ} \mathrm{C}$. Histone-DNA immunocomplexes were incubated for $2 \mathrm{~h}$ at $4{ }^{\circ} \mathrm{C}$ with protein $\mathrm{A}$ agarose beads and washed with appropriate buffers as recommended by the manufacturer (buffers were purchased from Millipore; \#17-295). Elution was performed in $0.1 \mathrm{M} \mathrm{NaHCO}_{3}$ with $1 \%$ SDS. HistoneDNA crosslinks were released by incubation for $6 \mathrm{~h}$ at $65^{\circ} \mathrm{C}$. ChIP-DNA was isolated using the QIAamp ${ }^{\circledR}$ DNA Mini kit (QIAGEN; \#51304) and used for PCR. Primers used to detect ribosomal genes have been previously described (Horáková et al. 2010).

\section{Nucleolar organizer regions (NORs) staining}

Cells were treated for 15 min with $75 \mathrm{mM} \mathrm{KCl}$ at $37^{\circ} \mathrm{C}$, fixed with methanol/acetic acid mix $(3: 1)$, and placed at $-20^{\circ} \mathrm{C}$ for $30 \mathrm{~min}$. Cell nuclei were spread on microscope slides and dehydrated in $70 \%, 80 \%$, and $96 \%$ ethanol (cooled at $-20{ }^{\circ} \mathrm{C}$ ) for $1 \mathrm{~min}$ each. Nuclei were stained for $30 \mathrm{~min}$ in the dark, and the following mixtures were used for staining: mixture A (2\% gelatin dissolved in double distilled water $\left[\mathrm{ddH}_{2} \mathrm{O}\right]$ and $1 \%$ formic acid) and mixture $\mathrm{B}\left(50 \% \mathrm{AgNO}_{3}\right.$ dissolved in $\mathrm{ddH}_{2} \mathrm{O}$ ). Mixture A and $\mathrm{B}$ were diluted at a 1:2 ratio. Nuclei were stained for 15 min using Eosin Y solution (Sigma-Aldrich; \#HT110180). Specimens were dehydrated for $1 \mathrm{~min}$ in $96 \%, 80 \%$, and $70 \%$ ethanol at room temperature. Cells were mounted in Vectashield mounting medium (Vector Laboratories; \#H-1000) and analyzed using a Leica SP5 X confocal microscope. Morphology of silver (Ag) stained NORs was inspected under transmission light.
F-actin filament visualization after treatment with CARM1 modulators

F-actin, as a protein of cytoskeleton, was visualized by FITC-conjugated phalloidin (\#P5282; Sigma-Aldrich, Czech Republic).

\section{Statistical analysis}

For statistical analysis we used Student's t-tests, calculated by the Sigma Plot software (version 13.0; Jandel Scientific). As statistically significant differences between parameters measured in control and treated cells we considered values at $\mathrm{p} \leq 0.05$. Significantly decreased values from control samples are marked by asterisks $(*)$; increased values are pointed out by sign (\#). Student's $\mathrm{t}$-test was performed for statistical analysis.

\section{Results}

Effects of CARM1 modulators on cell growth and cytoskeleton morphology

Cell lines were treated with appropriate concentrations of the CARM1 activator (EML159, Fig. 1Aa) or CARM1 inhibitor (ellagic acid, EA, Fig. $1 \mathrm{Ab}$ ), which were verified by cell counting after exposure to selected treatments (Fig. 1Ba-c). The concentrations of CARM1 modulators were selected according to reduced cell numbers shown in Figure 1Ba-c. Studies were performed in non-treated mESCs (Fig. 1Ba), iPSCs (Fig. 1Bb), and hESCs (Fig. 1Bc), and after treatment with CARM1 modulators. In these experiments, EA reduced cell numbers in all cell types studied (Fig. 1Ba-c). By Western blots we tested if CARM1 modulators have ability to change the levels of corresponding histone post-translation modification. For these analyses we selected asymmetric H3R17me2. We found that after EA treatment, level of H3R17me2 is decreased in hESCs (compare panels in Fig. 1Ca-d and quantification in panels Fig. 1Da-c).

Surprisingly, neither epi-drugs affected the morphology of cytoskeletal components, such as F-actin filaments (Fig. 2A-C), suggesting very low cytotoxic effects of drug concentration used. We used this analysis because many cytotoxic drugs, including modulators of epigenetic processes, affect cell morphology and induce apoptotic events (characterized by pronounced morphological changes, also well visible in cytoskeleton). Intriguingly, cell morphology was not affected by cell treatment with EA or EML (Fig. 2A-C). 

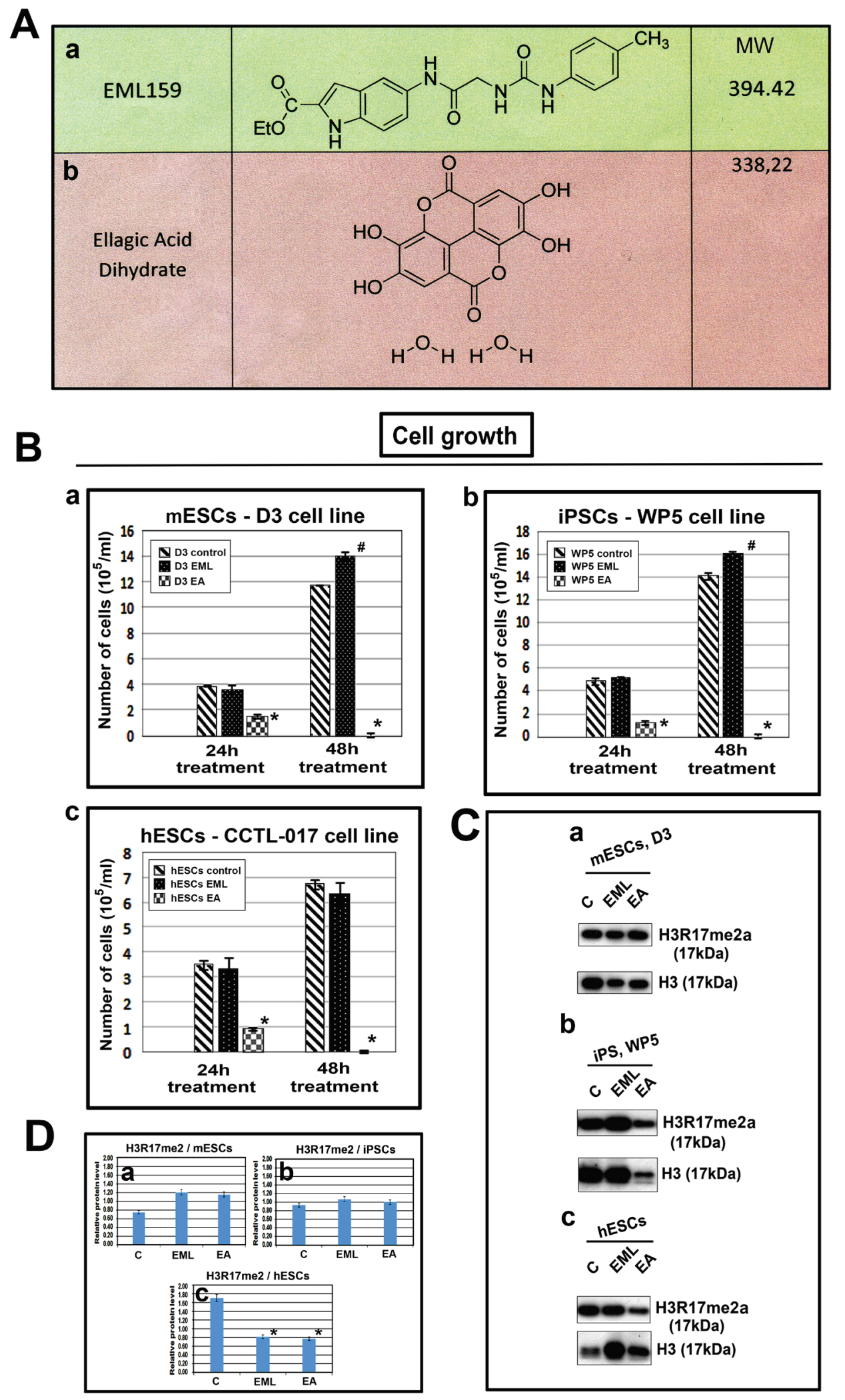

b

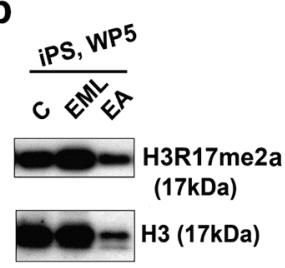

C

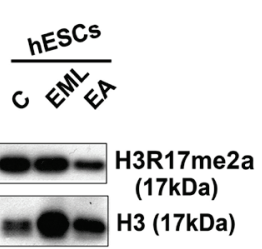

Fig. 1. Chemical formulas of CARM1 modulators and their effects on stem cell growth. Chemical formulas of (Aa) CARM1 activator (EML159) or (Ab) CARM1 inhibitor (ellagic acid dihydrate; EA). (B) Cell numbers measured by the TC10 (BioRad) automated cell counter in (a) mESCs (D3 cell line), (b) iPSCs (WP5 cell line), and (c) hESCs (CCTL-017 cell line). After seeding, cells were cultured for $24 \mathrm{~h}$, then CARM1 modulators were added, and cell numbers were counted after 24 and $48 \mathrm{~h}$ after addition of CARM1 modulators. (C) Western blot data showing the levels of asymmetric H3R17me2 in (a) mESCs, (b) iPSCs, and (c) hESCs. Normalization of entire H3R17me2 to H3 levels in control, EML and EA-treated cells is shown in panels (Da-c). Data in panels Ba-c and Da-c show the mean \pm standard errors (SE). Significantly decreased or increased values in panels Ba-c are shown by asterisks $(*)$ or by sign (\#) at $p \leq 0.05$. 


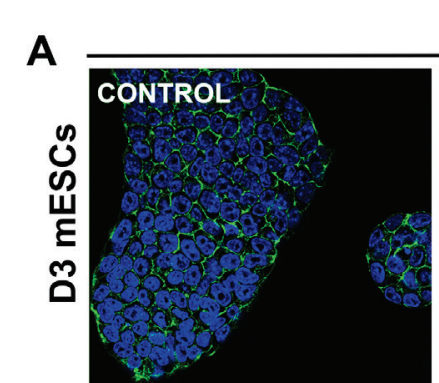

F-actin / Nuclei

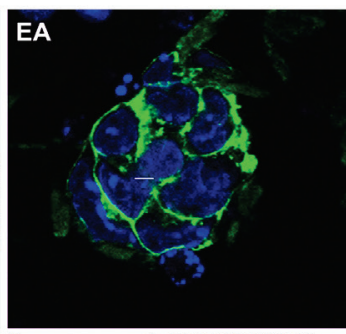

B

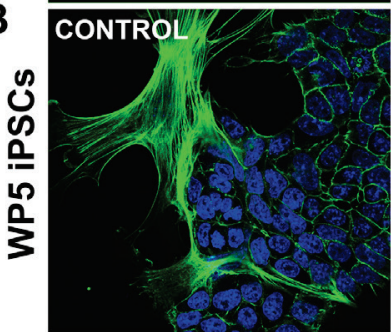

C

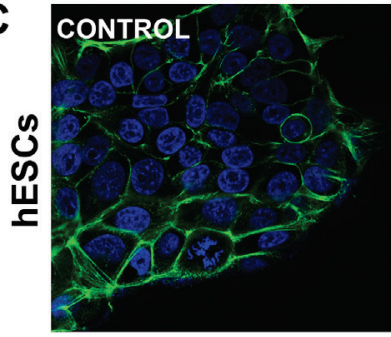

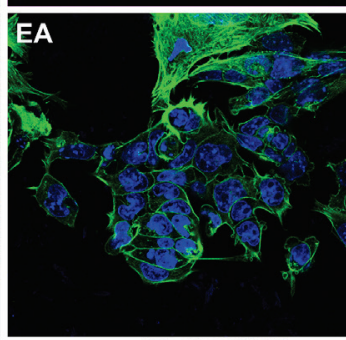

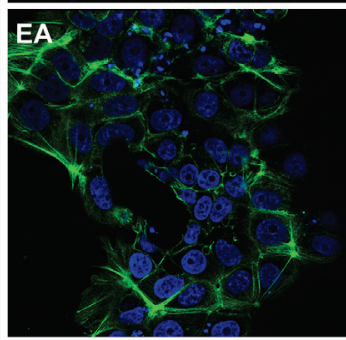

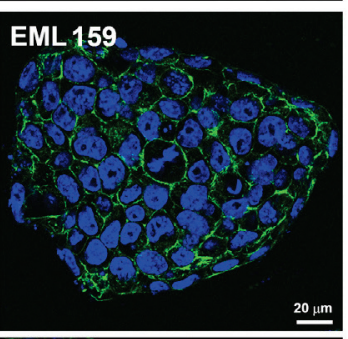

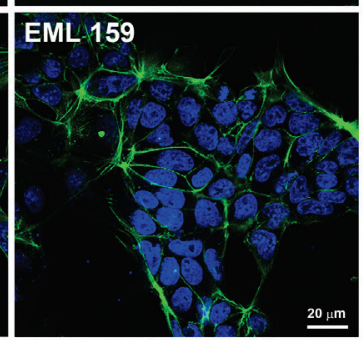

EML 159

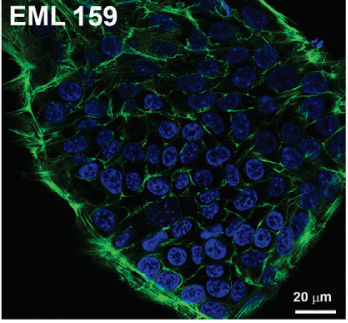

Fig. 2. Morphology of F-actin filaments after treating stem cells with CARM1 modulators. F-actin (green) was visualized using FITC-conjugated phalloidin (green) in the cells treated by CARM1 modulators for $24 \mathrm{~h}$ EML159 or ellagic acid as EA. Studies were performed in (A) mESCs (D3), (B) iPSCs (WP5), and (C) hESCs (CCTL-17).
CARM1 modulators caused changes in the levels of pluripotency markers

We next examined the effect of EML159 or EA on the levels of selected proteins studied by western blots. We analyzed the following proteins: OCT4, NANOG, an endoderm-like differentiation marker (Endo-A), proteins of nucleolus (fibrillarin or UBF1/2) and cytoskeletal protein $\alpha$-tubulin as reference protein (Fig. 3A-D). We observed different trends in protein levels in the three cell lines tested (mESCs, mouse iPSCs, and hESCs) after treatment with the two CARM1 modulators (Fig. 3A-D). For example, particularly in iPSCs, EA decreased the levels of the pluripotency markers, OCT4 and NANOG, whereas the levels of these proteins increased after EML159 treatment. In mouse ESCs, treatment by EML159 decreased OCT4 and NANOG levels, which was accompanied by an increased level of Endo-A (Fig. 3Da-c, data normalized to $\alpha$-tubulin are shown; average values from three independent biological replicates are shown in Supplementary Fig. 1A-C). Similarly, NANOG level was reduced, while Endo-A level was increased in hESCs affected by EML159 (Fig. 3Db, c; Supplementary Fig. 1B, C). OCT4 levels we also studied by immunofluorescence and this experimental approach confirmed a reduced level of OCT4 protein in iPSCs treated by EA, but not by
EML159 (see representative images in Fig. 4). The same was observed for mESCs and hESCs (not shown).

Proteins of nucleolus were also affected by CARM1 modulators: Increased level of fibrillarin was found in iPSCs after EML159 treatment and in hESCs fibrillarin level was enhanced after both EML159 and EA treatment (Fig. 3Dd, data normalized to $\alpha$-tubulin are shown; Supplementary Fig. 1D). UBF level was increased in mESCs after EML159 treatment and in iPSCs after EA (Fig. 3De), while decreased levels of UBF were found in iPSCs after EML159 treatment and in hESCs treated by both EML159 and EA (Fig. 3De, data were normalized to $\alpha$-tubulin levels; Supplementary Fig. 1E).

Changes in nucleoli after treatment with CARM1 modulators

Nucleoli function is predominantly related to transcription of ribosomal genes, which ensures synthesis of ribosomal sub-units. Three compartments can be recognized in the nucleolus: the fibrillar centers (FC), the dense fibrillar components (DFC), and the granular component (GC) (Koberna et al. 2002). Because the main protein of the FC is fibrillarin, we recognized nucleoli of mESCs, iPSCs, and hESCs according to the pattern of fibrillarin, visualized by immunofluorescence (Fig. 5A). 


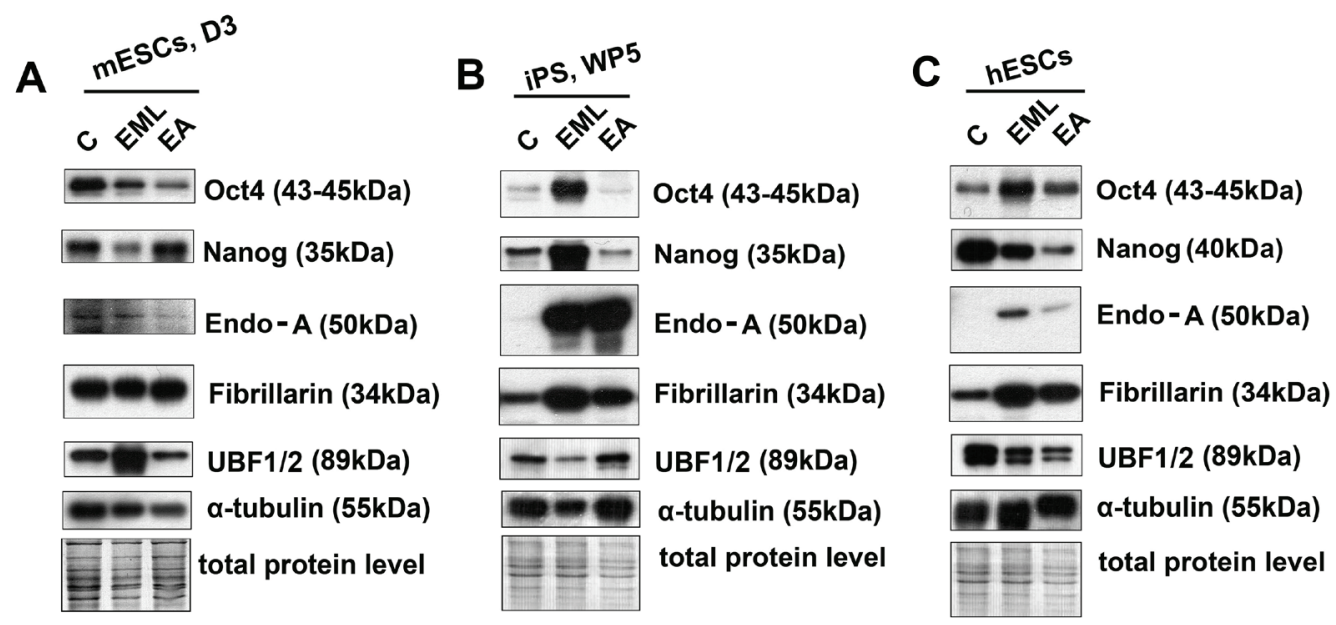

D
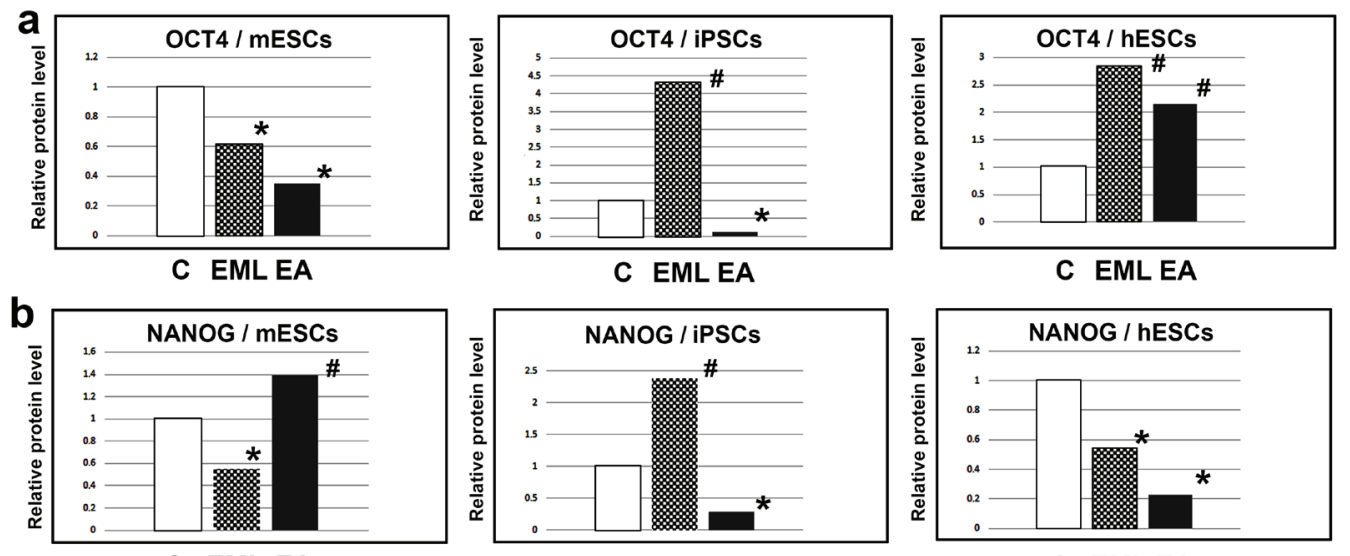

C EML EA

C EML EA

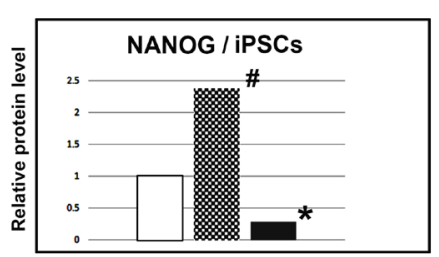

C EMLEA

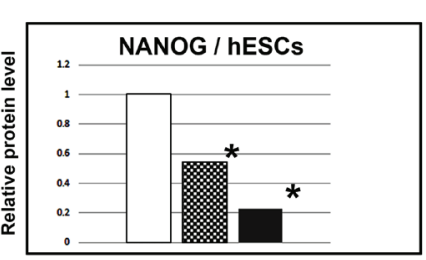

C EML EA

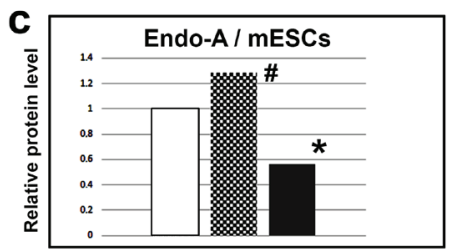

C EML EA

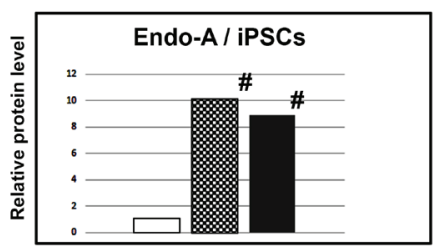

C EML EA

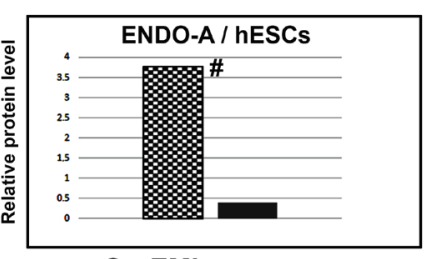

C EML EA

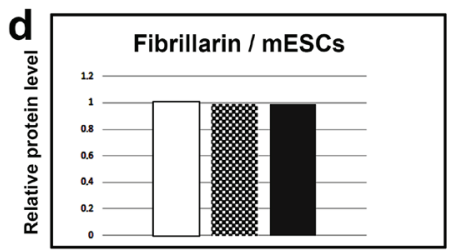

C EML EA

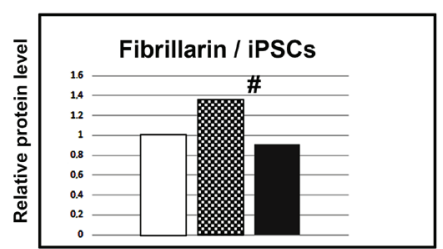

C EMLEA

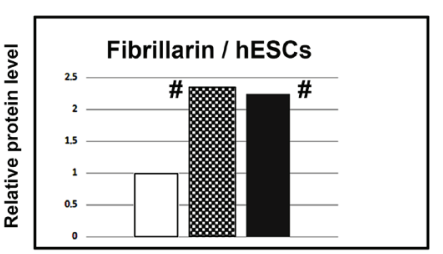

C EMLEA
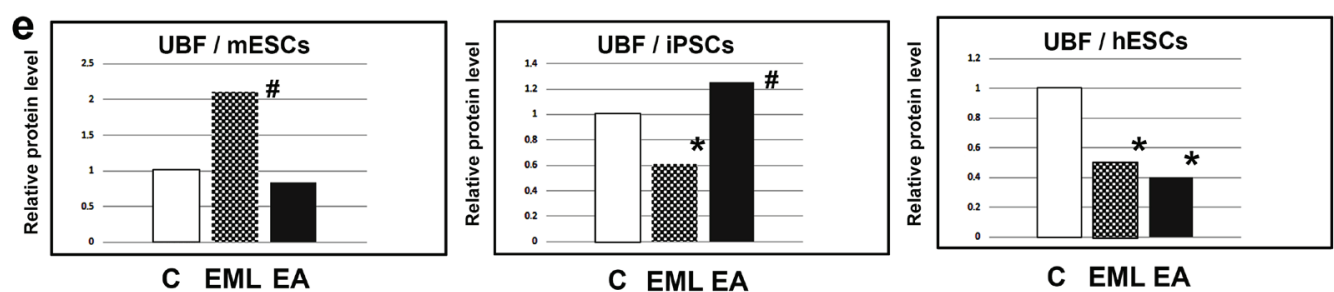

Fig. 3. Protein levels and quantification after treatment of stem cells with CARM1 modulators. Protein expression was evaluated in (A) mouse ESCS (D3), (B) mouse iPSCs (WP5), and (C) human ESCS (CCTL-017). The following proteins were evaluated: OCT4, NANOG, Endo-A, fibrillarin, UBF1/2 and a-tubulin. Protein levels were normalized to total protein levels and a-tubulin levels. Total protein levels, measured by $\mu Q$ uant spectrometers, are shown for each cell line analyzed. (D) Panels show quantification of OCT4, NANOG, Endo-A, fibrillarin, and UBF1/2 (normalized to a-tubulin levels). Quantification of the density of western blot fragments was performed by Image] software (freeware, NIH, USA). 
We analyzed the nuclear pattern of fibrillarin in parallel with asymmetrically di-methylated arginines of all proteins. We observed a high level of arginine dimethylation in control and EML159-treated hESC nucleoli (Fig. 5A, white arrows indicate nucleoli). However, EA remarkably reduced the levels of all asymmetrically di-methylated proteins in fibrillarinpositive regions of nucleoli (see white arrow in Fig. 5A, panel for EA). For control, we performed immunofluorescence staining without primary antibody and this experimental approach showed negative results in comparison with samples incubated with primary antibody against asymmetric arginine dimethylation (Fig. 5B).

As mentioned above, by performing quantitative western blots, especially in iPSCs and hESCs, we observed increased levels of fibrillarin, particularly after EML159 treatment (Fig. 3Dd; Supplementary Fig. 1D). To verify these results, we additionally analyzed fibrillarin-positive regions of nucleoli by immunofluorescence (Fig. 5A). Quantification of fluorescence intensity of immunostained nuclei or nucleoli is always problematic because of different fluorescence intensity in various regions on microscope slides. Therefore, instead, we measured diameter of nucleoli in control, EML or EA treated cells. We found a reduced diameter of nucleoli in EA treated hESCs, but no changes were observed in D3 mESCs (Fig. 5C). Conversely, an increased diameter of nucleoli was found when iPSCs were treated by EML (Fig. 5C). Together, EML and EA did not change the level of fibrillarin in mESCs, but EML increased the level of fibrillarin in iPSCs and both EML and EA increased the level of this protein in hESCs (Fig. 3Dd). Comparing this with the level of asymmetric H3R17me2 (Fig. 1Ca-c, Da-c), trends were different. Thus, we can only summarized that there is no link between fibrillarin and H3R17me2 levels (Fig. 1C, D, Fig. 3Dd, Supplementary Fig. 1D).

Because of morphological and epigenetics changes induced in nucleoli by selected CARM1 modulators, we additionally used ChIP-PCR to study asymmetric H3R17me2 in ribosomal genes. We studied rDNA promoter and rDNA encoding 28S rRNA. By these experiments we confirmed that EA has ability to affect compartment of nucleoli: EA reduced asymmetric H3R17me2 in rDNA promoter and rDNA encoding 28S rRNA (Fig. 6A, quantification in B). The direct effect of EA on nucleoli was also confirmed by analyzing morphology of AgNORs (Fig. 7A-C). In particular, in human ES cells, nucleoli were compact after EA treatment compared to non-treated cells (Fig. 7C). In contrast, morphological changes of nucleoli, induced by EML, were only observed in mESCs, D3 cell line (Fig. 7B). These data unambiguously identify EA as a potential modulator of nucleolar morphology and histone $\mathrm{H} 3$ arginine methylation in nucleoli, and thus, in ribosomal genes. It is likely that EA has ability to affect the epigenome as well as the function of the main nucleolar components, the ribosomal genes. These data are corroborated by the observation that similar AgNORs morphology (condensation of AgNORs) was observed after EA treatment as well as after inhibition of RNA polymerase I using actinomycin D (compare Fig. 7C and 7D).

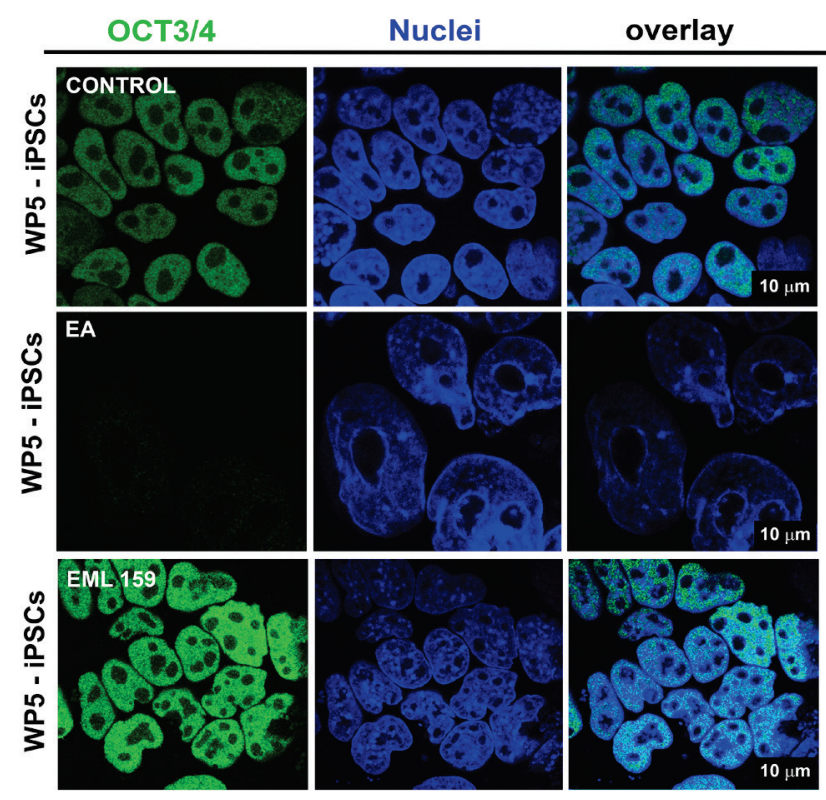

Fig. 4. Nuclear pattern of OCT 4 in iPSCs treated with CARM 1 modulators. Using immunofluorescence and confocal microscopy, OCT4 (green) levels were visualized in iPSC nuclei (blue). These cells were treated with EML159 or EA and effects of CARM1 modulators on OCT4 morphology were compared with morphology non-treated control cells. Image acquisition was performed using a Leica SP5 X confocal microscope. 
A Fibrillarin di-methylated arginine Nuclei overlay
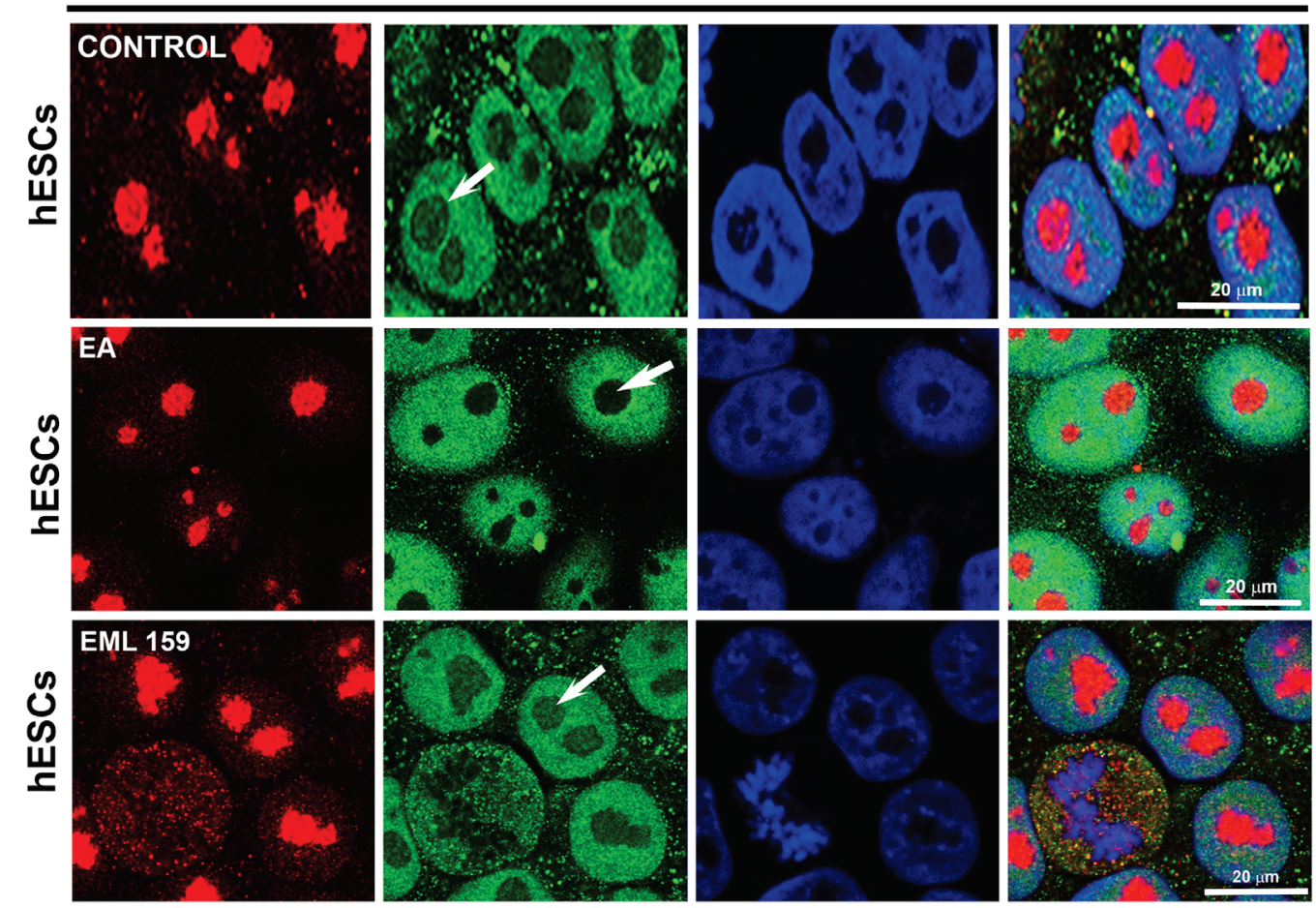

B
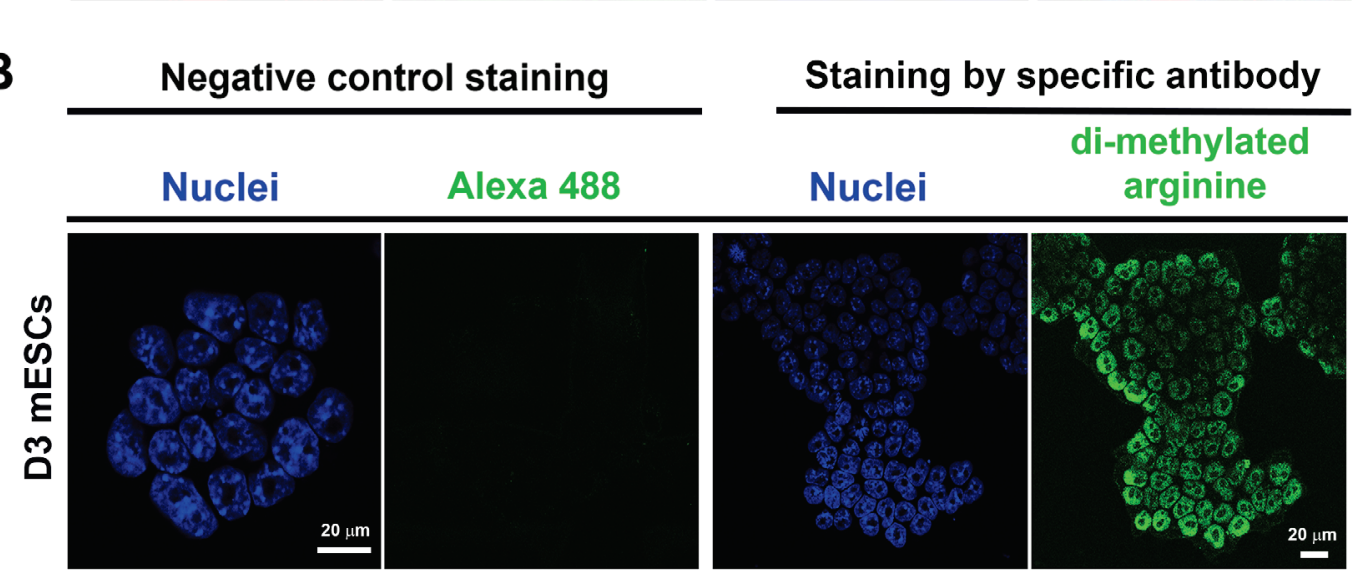

C
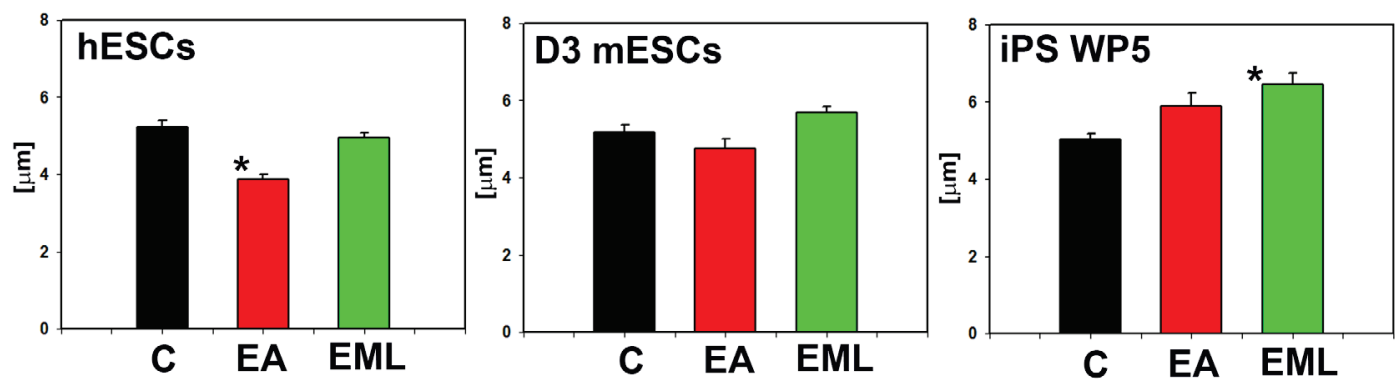

Fig. 5. Pattern and density of proteins with asymmetrically-di-methylated arginines in human ESCs and morphology of nucleoli. (A) Pan-arginine di-methylation (green) was studied in nucleolar compartments visualized using the fibrillarin antibody (red) in human ESCs (line CCTL-017) (blue). Nucleoli are shown by arrows. Human ESCs were treated with EA or EML159. Pan-arginine di-methylation and nucleoli were also visualized in non-treated control cells. Image acquisition was performed using confocal microscopy. (B) Negative control staining in an absence of primary antibody (secondary antibody was conjugated with Alexa 488) is shown. This was compared with positive control staining by antibody against dimethylation of all protein arginines (anti-ASYM24; \#07-414, Millipore) (green). Cell nuclei were visualized by DAPI staining (blue). (C) Diameter of nucleoli after the cell treatment by EA or EML compounds in comparison to control non-treated cells. Measurement was performed in hESCs, mESCs and iPSCs. Data are shown as mean \pm standard errors (SE). Significantly changed values at $\mathrm{p} \leq 0.05$ are shown by asterisks $\left(^{*}\right)$. Student's t-test was performed for statistical analysis. 
A

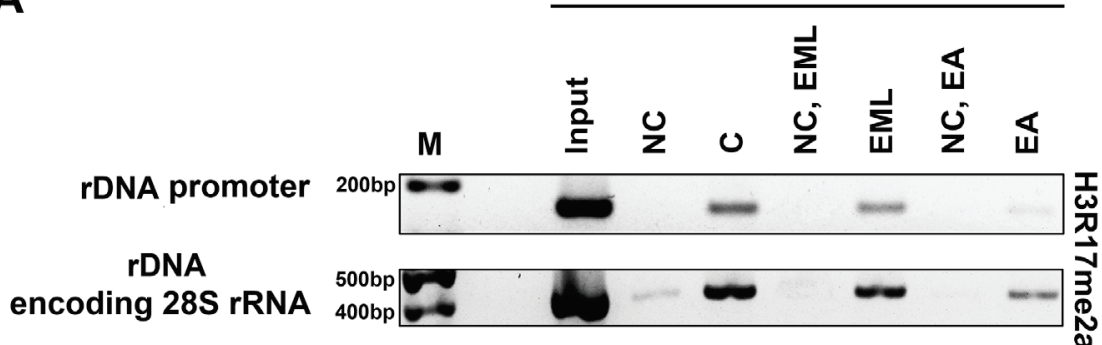

B
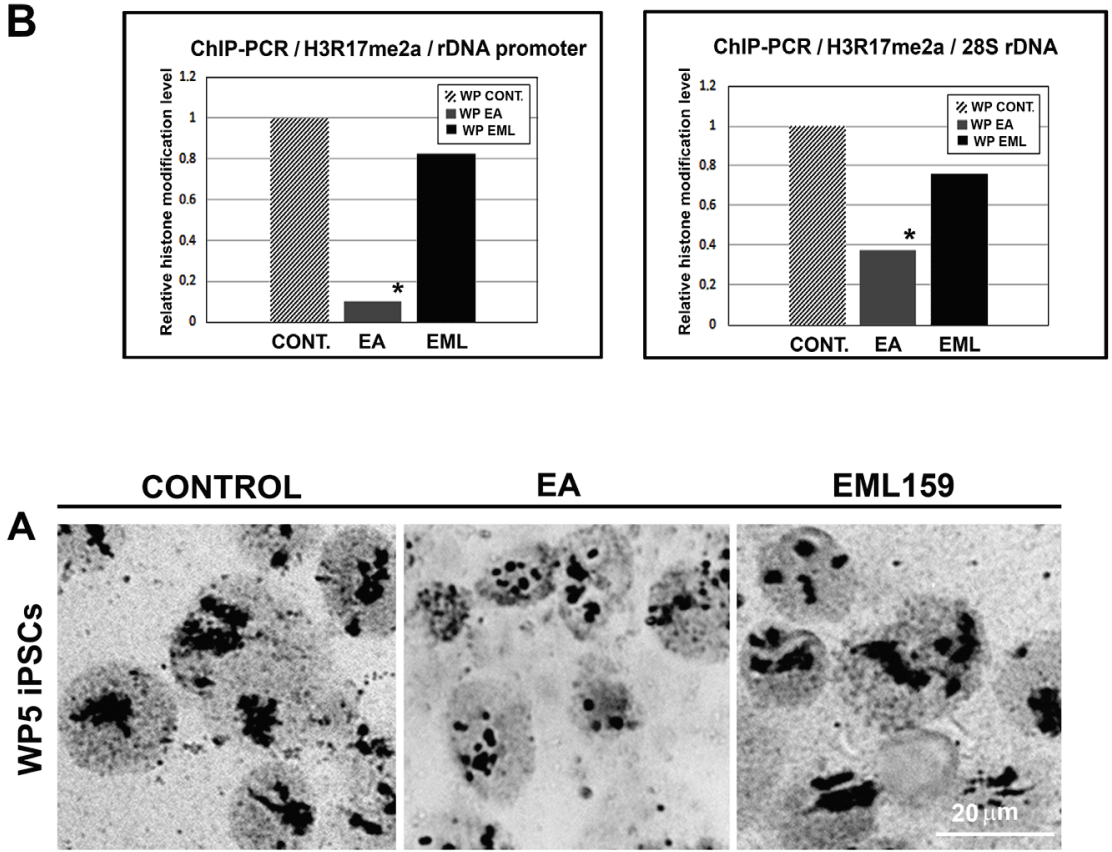

EA

EML159

B
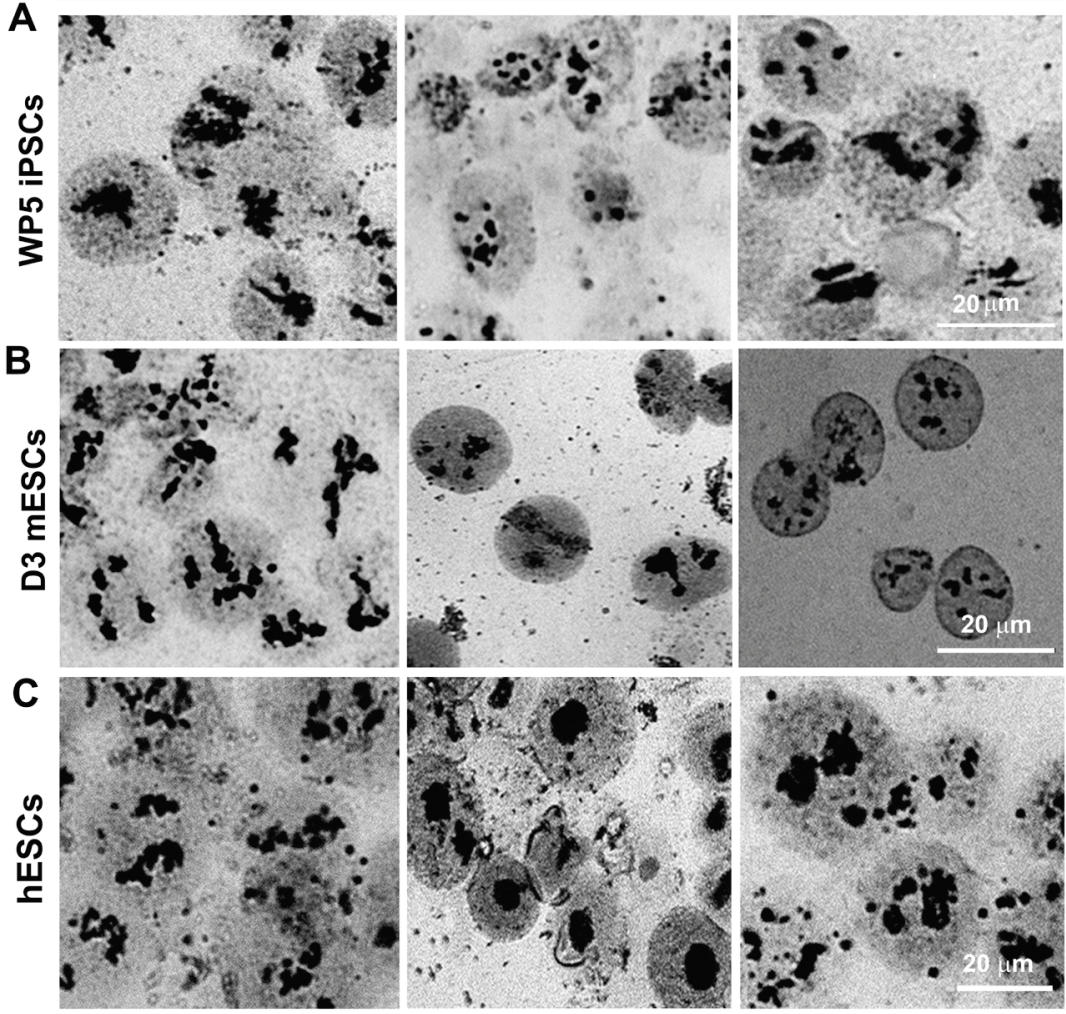

hESCs treated by Actinomycin D

D
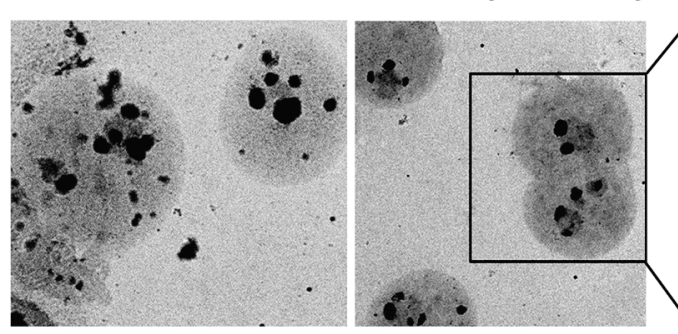

Fig. 6. Asymmetric H3R17 dimethylation levels were examined in non-treated hESCs and these cells treated with EML159 or EA. (A) ChIPPCR was used and the promoter of ribosomal genes (rDNA) and rDNA encoding 28S rRNA was studied. "NC" indicates negative control and " $\mathrm{C}$ " indicates control non-treated cells. (B) Quantification of ChIP-PCR results from panel A. Asterisk $(*)$ denotes significantly different data from control values at $p \leq 0.01$ as determined using Student's t-tests (Sigma Plot software, version 13.0; Jandel Scientific). For ChIP-PCR, following antibody was used: antihistone H3 asymmetric R17me2 (ChIP grade; \#ab8284, Abcam).

Fig. 7. Morphology of AgNORs after cell treatment with CARM1 modulators. AgNORs (black) were studied in (A) iPSCS (WP5), (B) mESCs (line D3), (C) hESCs (line CCTL-017), and (D) hESCs after treatment with the RNA polymerase I inhibitor actinomycin D. AgNORs were visualized in control non-treated cells and cells exposed to EML159 or EA epigenetic modulators. AgNORs were well visible under transmitted light as black regions inside the cell nuclei (gray). Visualization was performed by a wide field microscopy. 


\section{Discussion}

Nuclear events can be modified by small molecular compounds that influence the activity of histone-modifying enzymes. Histone deacetylases (HDACs) inhibitors, as well as inhibitors of PRMT1 arginine methyltransferase, alter nuclear morphology and nuclear protein kinetics (Bartolini et al. 2005, Gilchrist et al. 2004, Stixová et al. 2011, Suchánková et al. 2014). "Epi-drugs" could therefore be of clinical significance, particularly in light of emerging therapeutic interventions targeting the epigenome. In fact, HDACs inhibitors, which target genes involved in cell cycle regulation, apoptosis, and replication, have already shown therapeutic promise, particularly in anti-cancer therapy (Chen et al. 2011, Marks 2010, Peart et al. 2005). Additionally, small molecule inhibitors of acetylated histone lysines by BET family proteins had significant effects in pre-clinical models, and could lead to the identification of new anti-leukemia drugs (Wyspianska et al. 2014). Thus, analyses of the effects of epi-drugs on cell growth and the induction of apoptosis and gene expression represent the first steps before testing in animal models and subsequent clinical trials (Legartová et al. 2013, Wyspianska et al. 2014).

Here, we support the conclusions on the importance of CARM1 function for stem cell pluripotency. This summary is based on our observation on reduced OCT4 or NANOG levels and increased expression of Endo-A after CARM1 modulation (Fig. 3A-D). This trend was observed in many events tested and this is in agreement with previous studies showing that CARM1-mediated H3 arginine methylation predisposes blastomere to contribute to the pluripotency of cells in the inner cell mass. This CARM1 functional characteristics was found to be linked to a high level of pluripotency factors, including NANOG and Sox2 (Torres-Padilla et al. 2007, Wu et al. 2009). Moreover, we showed that CARM1 inhibition by EA affects nucleolar morphology in ES and iPS cells. This intervention to epi-genome influenced not only AgNORs morphology, but also asymmetric di-methylation (H3R17me2a), particularly in ribosomal genes (Figs 6 and 7). These data are congruent with the fact that actinomycin D, a RNA polymerase I inhibitor, alters nucleolar morphology in a similar manner to our observations of EA-treated cells (Fig. 7A-D). For example, a crescent-like shape of fibrillarin-positive nucleolar regions appears after actinomycin D treatment
(Horáková et al. 2010) and a similar pattern of nucleoli or condensation of AgNORs we observed after EA or actinomycin D treatment of mESCs, iPSCs, and hESCs (Fig. 7A-D). These morphological changes could be associated with a reduced transcription of ribosomal genes, which is consistent with the CARM1-inhibitory effect of EA. Moreover, CARM1 is widely regarded as a co-regulator of the expression of many protein-coding genes (Chen et al. 1999, Purandare et al. 2008, Therrien et al. 2009). Therefore, it is likely that CARM1 could also regulate ribosomal gene transcription via H3R17 asymmetric di-methylation especially in the promoter regions of ribosomal genes. Here, we demonstrate EAinduced decrease in H3R17me2a in ribosomal genes (Fig. 6A-B), which is an epigenetic sign of gene downregulation ( $\mathrm{Wu}$ et al. 2009). Moreover, methylation of non-histone proteins involved in transcription machinery also contributes to global expression of protein-coding genes (Chen et al. 1999). Interestingly, this outcome also agrees with a previous study reporting that CARM1 also methylates several splicing factors and potentially regulates alternative pre-mRNA splicing (Cheng and Bedford 2011). Therefore, our data contribute to the statement that CARM1-related transcriptional and posttranscriptional regulation is of immense biological significance.

\section{Conclusions}

In summary, we showed for the first time that modulation of CARM1 activity affects the epigenetic profile of ribosomal genes and morphology of nucleoli of ES and iPS cells. Interestingly, tested CARM1 modulators did not affect cytoskeleton, but significantly changed pattern of nucleoli; especially AgNORs nuclear pattern was affected by ellagic acid (Figs 5A and 7A-C). This effect seems to be mostly demanding in tumor cells, characterized by multiple nucleoli and aberrant morphology of AgNORs (Derenzini 2000). Thus, our observation shed a light on importance of CARM1 modulators and their effects on epigenome of ribosomal genes as main compounds of nucleoli.

\section{Conflict of Interest}

There is no conflict of interest.

\section{Acknowledgements}

Stanislav Kozubek coordinated the GACR projects $\mathrm{P} 302 / 10 / 1022$ and $\mathrm{P} 302 / 12 / \mathrm{G} 157$ that supported this 
research. Eva Bártová is a principal investigator of GACR project 13-07822S. Synthesis of the small molecular compounds EML159 and ellagic acid was supported by the Italian Ministry of Education, Universities, and Research (project PRIN 20103W4779). Michal Franek is a principal investigator of Ph.D. project: „Brno Ph.D. Talent“, funded by the City Municipality of Brno, Czech Republic.

\section{Abbreviations}

Asymmetric di-methylation of arginine residues at histone $\mathrm{H} 3$ at positions 17 or 26 (H3R17me2a or
H3R26me2a); Bovine serum albumin (BSA); Chromatin immunoprecipitation (ChIP); Dense fibrillar components (DFC); Dulbecco's Modified Eagle Medium (DMEM); Ellagic acid dihydrate (EA); Fibrillar Centers (FC); Fluorescein isothiocyanate (FITC); Granular component (GC); Histone deacetylases (HDACs); Human and mouse embryonic stem cells (hESCs and mESCs); Induced pluripotent stem cells (iPSCs); Phosphate buffered saline (PBS); Polymerase chain reaction (PCR); Ribosomal DNA (rDNA); Silver-stained (Argyrophilic) Nucleolus Organizer Regions (AgNORs)

\section{References}

ALBERTS B, JOHNSON A, LEWIS J, RAFF M, ROBERTS K, WALTER P: The cytoskeleton. In: Molecular Biology of the Cell, $4^{\text {th }}$ Ed. Garland Science, New York, 2002, pp 907-982.

ALLAN M, MANKU S, THERRIEN E, NGUYEN N, STYHLER S, ROBERT MF, GOULET AC, PETSCHNER AJ, RAHIL G, ROBERT MACLEOD A, DEZIEL R, BESTERMAN JM, NGUYEN H, WAHHAB A: N-benzyl1-heteroaryl-3-(trifluoromethyl)-1H-pyrazole-5-carboxamides as inhibitors of co-activator associated arginine methyltransferase 1 (CARM1). Bioorg Med Chem Lett 19: 1218-1223, 2009.

BARTOLINI S, MAI A, ARTICO M, PAESANO N, ROTILI D, SPADAFORA C, SBARDELLA G: 6-[1-(2,6difluorophenyl)ethyl]pyrimidinones antagonize cell proliferation and induce cell differentiation by inhibiting (a nontelomeric) endogenous reverse transcriptase. J Med Chem 48: 6776-6778, 2005.

BATUT J, DUBOE C, VANDEL L: The methyltransferases PRMT4/CARM1 and PRMT5 control differentially myogenesis in zebrafish. PloS One 6: e25427, 2011.

BONHAM K, HEMMERS S, LIM YH, HILL DM, FINN MG, MOWEN KA: Effects of a novel arginine methyltransferase inhibitor on T-helper cell cytokine production. FEBS J 277: 2096-2108, 2010.

CASTELLANO S, MILITE C, RAGNO R, SIMEONI S, MAI A, LIMONGELLI V, NOVELLINO E, BAUER I, BROSCH G, SPANNHOFF A, CHENG D, BEDFORD MT, SBARDELLA G: Design, synthesis and biological evaluation of carboxy analogues of arginine methyltransferase inhibitor 1 (AMI-1). ChemMedChem 5: 398-414, 2010.

CASTELLANO S, SPANNHOFF A, MILITE C, DAL PIAZ F, CHENG D, TOSCO A, VIVIANO M, YAMANI A, CIANCIULli A, SALA M, CURA V, CAVARELli J, NOVELlinO E, MAI A, BEDFORD MT, SBARDELLA G: Identification of small-molecule enhancers of arginine methylation catalyzed by coactivatorassociated arginine methyltransferase 1. J Med Chem 55: 9875-9890, 2012.

CHEN D, MA H, HONG H, KOH SS, HUANG SM, SCHURTER BT, ASWAD DW, STALLCUP MR: Regulation of transcription by a protein methyltransferase. Science 284: 2174-2177, 1999.

CHEN MY, LIAO WS, LU Z, BORNMANN WG, HENNESSEY V, WASHINGTON MN, ROSNER GL, YU Y, AHMED AA, BAST RC Jr: Decitabine and suberoylanilide hydroxamic acid (SAHA) inhibit growth of ovarian cancer cell lines and xenografts while inducing expression of imprinted tumor suppressor genes, apoptosis, G2/M arrest, and autophagy. Cancer 117: 4424-4438, 2011.

CHENG D, BEDFORD MT: Xenoestrogens regulate the activity of arginine methyltransferases. Chembiochem 12: $323-$ $329,2011$.

CHENG D, VALENTE S, CASTELLANO S, SBARDELlA G, Di SANTO R, COSTI R, BEDFORD MT, MAI A: Novel 3,5-bis(bromohydroxybenzylidene)piperidin-4-ones as coactivator-associated arginine methyltransferase 1 inhibitors: enzyme selectivity and cellular activity. J Med Chem 54: 4928-4932, 2011. 
CHENG H, QIN Y, FAN H, SU P, ZHANG X, ZHANG H, ZHOU G: Overexpression of CARM1 in breast cancer is correlated with poorly characterized clinicopathologic parameters and molecular subtypes. Diagn Pathol 8: $129,2013$.

COVIC M, HASSA PO, SACCANI S, BUERKI C, MEIER NI, LOMBARDI C, IMHOF R, BEDFORD MT, NATOLI G, HOTTIGER MO: Arginine methyltransferase CARM1 is a promoter-specific regulator of NFkappaB-dependent gene expression. EMBO J 24: 85-96, 2005.

DERENZINI M: The AgNORs. Micron 31: 117-120, 2000.

DOWDEN J, PIKE RA, PARRY RV, HONG W, MUHSEN UA, WARD SG: Small molecule inhibitors that discriminate between protein arginine N-methyltransferases PRMT1 and CARM1. Org Biomol Chem 9: 7814$7821,2011$.

GILCHRIST S, GILBERT N, PERRY P, BICKMORE WA: Nuclear organization of centromeric domains is not perturbed by inhibition of histone deacetylases. Chromosome Res 12: 505-516, 2004.

HABASHY HO, RAKHA EA, ELLIS IO, POWE DG: The oestrogen receptor coactivator CARM1 has an oncogenic effect and is associated with poor prognosis in breast cancer. Breast Cancer Res Treat 140: 307-316, 2013.

HORÁKOVÁ AH, BÁRTOVÁ E, GALIOVÁ G, UHLÍŘOVÁ R, MATULA P, KOZUBEK S: SUV39h-independent association of HP1 beta with fibrillarin-positive nucleolar regions. Chromosoma 119: 227-241, 2010.

HUYNH T, CHEN Z, PANG S, GENG J, BANDIERA T, BINDI S, VIANELLO P, ROLETTO F, THIEFFINE S, GALVANI A, VACCARO W, POSS MA, TRAINOR GL, LORENZI MV, GOTTARDIS M, JAYARAMAN L, PURANDARE AV: Optimization of pyrazole inhibitors of Coactivator Associated Arginine Methyltransferase 1 (CARM1). Bioorg Med Chem Lett 19: 2924-2927, 2009.

ITO T, YADAV N, LEE J, FURUMATSU T, YAMASHITA S, YOSHIDA K, TANIGUCHI N, HASHIMOTO M, TSUCHIYA M, OZAKI T, LOTZ M, BEDFORD MT, ASAHARA H: Arginine methyltransferase CARM1/PRMT4 regulates endochondral ossification. BMC Dev Biol 9: 47, 2009.

KAWABE Y, WANG YX, MCKINNELL IW, BEDFORD MT, RUDNICKI MA: Carm1 regulates Pax7 transcriptional activity through MLL1/2 recruitment during asymmetric satellite stem cell divisions. Cell Stem Cell 11: 333$345,2012$.

KIM J, LEE J, YADAV N, WU Q, CARTER C, RICHARD S, RICHIE E, BEDFORD MT: Loss of CARM1 results in hypomethylation of thymocyte cyclic AMP-regulated phosphoprotein and deregulated early $T$ cell development. J Biol Chem 279: 25339-25344, 2004.

KOBERNA K, MALÍNSKY J, PLISS A, MAŠATA M, VEČEŘOVÁ J, FIALOVÁ M, BEDNÁR J, RAŠKA I: Ribosomal genes in focus: new transcripts label the dense fibrillar components and form clusters indicative of "Christmas trees" in situ. J Cell Biol 157: 743-748, 2002.

LEGARTOVÁ S, JUGOVÁ A, STIXOVÁ L, KOZUBEK S, FOJTOVÁ M, ZDRÁHAL Z, LOCHMANOVÁ G, BÁRTOVÁ E: Epigenetic aspects of HP1 exchange kinetics in apoptotic chromatin. Biochimie 95: 167-179, 2013.

MARKS PA: The clinical development of histone deacetylase inhibitors as targeted anticancer drugs. Expert Opin Investig Drugs 19: 1049-1066, 2010.

O'BRIEN KB, ALBERICH-JORDA M, YADAV N, KOCHER O, DIRUSCIO A, EBRALIDZE A, LEVANTINI E, SNG NJ, BHASIN M, CARON T, KIM D, STEIDL U, HUANG G, HALMOS B, RODIG SJ, BEDFORD MT, TENEN DG, KOBAYASHI S: CARM1 is required for proper control of proliferation and differentiation of pulmonary epithelial cells. Development 137: 2147-2156, 2010.

OU CY, LABONTE MJ, MANEGOLD PC, SO AY, IANCULESCU I, GERKE DS, YAMAMOTO KR, LADNER RD, KAHN M, KIM JH, STALLCUP MR: A coactivator role of CARM1 in the dysregulation of $\beta$-catenin activity in colorectal cancer cell growth and gene expression. Mol Cancer Res 9: 660-670, 2011.

PEART MJ, SMYTH GK, VAN LAAR RK, BOWTELL DD, RICHON VM, MARKS PA, HOLLOWAY AJ, JOHNSTONE RW: Identification and functional significance of genes regulated by structurally different histone deacetylase inhibitors. Proc Natl Acad Sci USA 102: 3697-3702, 2005.

PURANDARE AV, CHEN Z, HUYNH T, PANG S, GENG J, VACCARO W, POSS MA, OCONNELL J, NOWAK K, JAYARAMAN L: Pyrazole inhibitors of coactivator associated arginine methyltransferase 1 (CARM1). Bioorg Med Chem Lett 18: 4438-4441, 2008. 
SACK JS, THIEFFINE S, BANDIERA T, FASOLINI M, DUKE GJ, JAYARAMAN L, KISH KF, KLEI HE, PURANDARE AV, ROSETTANI P, TROIANI S, XIE D, BERTRAND JA: Structural basis for CARM1 inhibition by indole and pyrazole inhibitors. Biochem J 436: 331-339, 2011.

SELVI BR, BATTA K, KISHORE AH, MANTELINGU K, VARIER RA, BALASUBRAMANYAM K, PRADHAN SK, DASGUPTA D, SRIRAM S, AGRAWAL S, KUNDU TK: Identification of a novel inhibitor of coactivator-associated arginine methyltransferase 1 (CARM1)-mediated methylation of histone H3 Arg-17. J Biol Chem 285: 7143-7152, 2010.

STIXOVÁ L, BÁRTOVÁ E, MATULA P, DANĚK O, LEGARTOVÁ S, KOZUBEK S: Heterogeneity in the kinetics of nuclear proteins and trajectories of substructures associated with heterochromatin. Epigenetics Chromatin 4:5, 2011.

STIXOVÁ L, MATULA P, KOZUBEK S, GOMBITOVÁ A, CMARKO D, RAŠKA I, BÁRTOVÁ E: Trajectories and nuclear arrangement of PML bodies are influenced by A-type lamin deficiency. Biol Cell 104: 418-432, 2012.

SUCHÁNKOVÁ J, LEGARTOVÁ S, SEHNALOVÁ P, KOZUBEK S, VALENTE S, LABELLA D, MAI A, ECKERICH C, FACKELMAYER FO, SOROKIN DV, BÁRTOVÁ E: PRMT1 arginine methyltransferase accumulates in cytoplasmic bodies that respond to selective inhibition and DNA damage. Eur $J$ Histochem 58:2389, 2014.

ŠUSTÁČKOVÁ G, LEGARTOVÁ S, KOZUBEK S, STIXOVÁ L, PACHERNÍK J, BÁRTOVÁ E: Differentiationindependent fluctuation of pluripotency-related transcription factors and other epigenetic markers in embryonic stem cell colonies. Stem Cells Dev 21: 710-720, 2012.

THERRIEN E, LAROUCHE G, MANKU S, ALLAN M, NGUYEN N, STYHLER S, ROBERT MF, GOULET AC, BESTERMAN JM, NGUYEN H, WAHHAB A: 1,2-diamines as inhibitors of co-activator associated arginine methyltransferase 1 (CARM1). Bioorg Med Chem Lett 19: 6725-6732, 2009.

TORRES-PADILLA ME, PARFITT DE, KOUZARIDES T, ZERNICKA-GOETZ M: Histone arginine methylation regulates pluripotency in the early mouse embryo. Nature 445: 214-218, 2007.

WAN H, HUYNH T, PANG S, GENG J, VACCARO W, POSS MA, TRAINOR GL, LORENZI MV, GOTTARDIS M, JAYARAMAN L, PURANDARE AV: Benzo[d]imidazole inhibitors of Coactivator Associated Arginine Methyltransferase 1 (CARM1) - Hit to Lead studies. Bioorg Med Chem Lett 19: 5063-5066, 2009.

WANG SC, DOWHAN DH, ERIKSSON NA, MUSCAT GE: CARM1/PRMT4 is necessary for the glycogen gene expression programme in skeletal muscle cells. Biochem J 444: 323-331, 2012.

WU Q, BRUCE AW, JEDRUSIK A, ELLIS PD, ANDREWS RM, LANGFORD CF, GLOVER DM, ZERNICKAGOETZ M: CARM1 is required in embryonic stem cells to maintain pluripotency and resist differentiation. Stem Cells 27: 2637-2645, 2009.

WYSPIANSKA BS, BANNISTER AJ, BARBIERI I, NANGALIA J, GODFREY A, CALERO-NIETO FJ, ROBSON S, RIOJA I, LI J, WIESE M, CANNIZZARO E, DAWSON MA, HUNTLY B, PRINJHA RK, GREEN AR, GOTTGENS B, KOUZARIDES T: BET protein inhibition shows efficacy against JAK2V617Fdriven neoplasms. Leukemia 28: 88-97, 2014.

YADAV N, LEE J, KIM J, SHEN J, HU MC, ALDAZ CM, BEDFORD MT: Specific protein methylation defects and gene expression perturbations in coactivator-associated arginine methyltransferase 1-deficient mice. Proc Natl Acad Sci USA 100: 6464-6468, 2003.

ZENG H, WU J, BEDFORD MT, SBARDELLA G, HOFFMANN FM, BI K, XU W: A TR-FRET-based functional assay for screening activators of CARM1. Chembiochem 14: 827-835, 2013. 